University of New Orleans

ScholarWorks@UNO

\title{
An empirical investigation of the existence of "market discipline" of off-balance sheet banking risk
}

M. Kabir Hassan

University of New Orleans

Follow this and additional works at: https://scholarworks.uno.edu/econ_wp

\section{Recommended Citation}

Hassan, M. Kabir, "An empirical investigation of the existence of "market discipline" of off-balance sheet banking risk" (1991). Department of Economics and Finance Working Papers, 1991-2006. Paper 49.

https://scholarworks.uno.edu/econ_wp/49

This Working Paper is brought to you for free and open access by the Department of Economics and Finance at ScholarWorks@UNO. It has been accepted for inclusion in Department of Economics and Finance Working Papers, 1991-2006 by an authorized administrator of ScholarWorks@UNO. For more information, please contact scholarworks@uno.edu. 


\title{
UNIVERSITY OF NEW ORLEANS
}

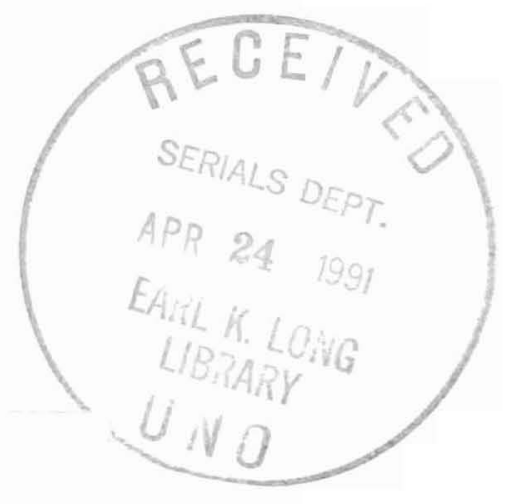

\begin{abstract}
An Empirical Investigation of the Existence of "Market Discipline" of off-Balance Sheet Banking Risk
\end{abstract}

M. Kabir Hassan*

Working Paper \# 5-91

\section{ECONOMICS AND FINANCE WORKING PAPER SERIES}

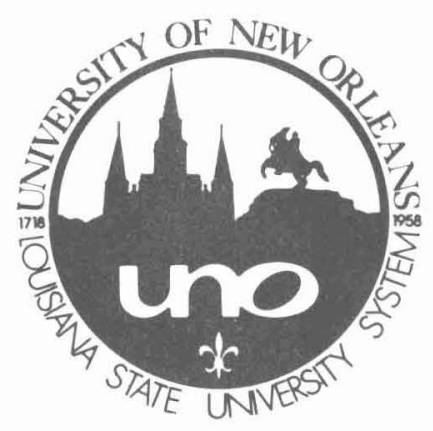

Department of

Economics and Finance

University of New Orleans 


\title{
An Empirical Investigation of the Existence of "Market Discipline" of \\ off-Balance Sheet Banking Risk
}

\section{Kabir Hassan*}

Working Paper \# 5-91

* Assistant Professor of Finance, Department of Economics and Finance, University of New orleans

For additional copies of this working paper or a current list of the papers available in this series, please contact:

\author{
Professor Nicholas Mercuro \\ Working Paper Series \\ Department of Economics and Finance \\ University of New Orleans \\ New Orleans, LA 70148 \\ phone:(504) 286-6270
}

Not for quotation or attribution without permission of authors.
All rights reserved.
COPYRIGHT ㅇ 1991 


\section{AN EMPIRICAL INVESTIGATION OF THE EXISTENCE OF "MARKET DISCIPLINE" OF OFF-BALANCE SHEET BANRING RISR}

Bank regulators are concerned with the dramatic increase and risk exposure of Off-Balance sheet (OBS) banking activities in recent years, and proposed that some OBS activities be included in the calculation of a risk-based capital requirement. This paper investigates the riskiness of oBs activities. Specifically, this paper reports on three capital market tests of OBS banking risk: the impact of OBS activities on the risk-premia of subordinated debt, on equity risk and on systematic risk of large commercial banks and bank holding companies. The underlying premise of this study is that the bank stockholders and subordinated debtholders are more exposed to the risk of bank failure resulting from oBS banking risk than insured and uninsured depositholders. If OBS activities are significantly related to market measures of bank risk, then "market discipline" of such activities exists. The empirical literature, to date, has ignored the impact of oBs banking risk on the default risk-premia borne by subordinated debtholders. The results indicate that most OBS activities reduce riskpremia and equity risk, but do not affect systematic risk. Both stockholders and subordinated debtholders price these oBs activities as risk-reducing. Therefore, regulatory interference in the form of additional capital requirement of oBs activities will penalize large commercial banks and will create distortions in the financial intermediation market. 


\section{Introduction}

Bank regulators are concerned with the dramatic increase in off-balance sheet (OBS) banking activities in recent years. Off-balance sheet activities are not summarized in dollars on the balance sheet but are instead given in the verbal footnotes to balance sheets. However, banks are required to report such activities to regulatory authorities. In off-balance sheet transactions, banks earn fee incomes instead of interest spreads, and loans are not held on the books.

As a result of these OBS activities, banks may face three general types of portfolio risk: credit risk on underwritten guarantees, interest rate risk due to liability mismatches on commitment takedowns and liquidity risk due to overextension of obligations. Unlike balance sheet items, these potential obligations are not funded with balance sheet liabilities and are not considered in determining a bank's regulatory capital requirements. On Ilarch 1, 1988, the Federal Reserve, in conjunction with other bank regulatory agencies and foreign central banks issued a risk-based capital proposal, which will be phased in by 1992, that some off-balance sheet items be included in calculating such a capital requirement.

A key rationale for 0BS banking capital regulation is an assumed information asymmetry between bank managers and liability holders. The regulatory presumption is that such OBS activities are risky and the market fails to recognize the risk embodied in such OBS activities. The "market discipline" studies of OBS banking risk have addressed the question of whether market prices of bank liabilities reflect the risk of OBS activities. If "market discipline" exists and off-balance sheet activities are found to be risk-sensitive, bank liability holders can distinguish OBS banking risk. The 
assumed information asymmetry rationale for capital regulation of OBS activities, therefore, becomes less convincing.

The purpose of this paper is to rigorously explore the riskiness and motivation of OBS banking activities. This research reports on three capital market tests of 0BS banking risk: the impact of OBS activities on the risk-premia of subordinated debt, on equity risk and on systematic risk of large commercial banks and bank holding companies. This research improves upon the existing evidence of OBS banking risk in three important ways. First, while the relationships between OBS activities and, total and systematic risks have been studied, the empirical literature, to date, has ignored the impact of 0BS risk on the default-risk premia borne by subordinated debt-holders. Second, this paper examines the riskiness of all 19 0BS items -- categorized into seven groups depending upon their similar characteristics -- from call and income reports of the FDIC tapes. Third, this study employs an etended data set ranging from 1984 to 1988. A pooled cross-section and time-series generalized least squares (GLS) estimation procedure is employed to examine the "market discipline" of OBS activities. The underlying premise of this study is that the bank stockholders and subordinated debtholders are more exposed to the risk of bank failure than depositholders. Therefore, their assessment of the riskiness of OBS activities is realistically determined.

\section{Previous Research}

The theoretical analysis of OBS banking activities primarily deals with the motivation and existence of such activities. The overriding conclusions of theoretical analyses are that (1) OBS activities are natural banking activities, and hence do not affect business risk of banking firms, (2) OBS activities 
provide diversification potential to bank stockholders, and hence reduce total risk but do not affect systematic risk, (3) OBS activities are potentially leverage increasing, and hence increase financial risk.

A number of competing hypotheses concerning risk-taking behavior of OBS items have been proposed in literature. A bank's activity in the market for off-balance sheet credit enhancement is a function of its willingness to accommodate the needs of its customers, the market's perception of bank's quality as reflected in balance sheet decisions and the incentives provided by the regulators. Theories of financial intermediation suggest that OBS banking activities are designed to provide credit enhancement services to its customers. By guaranteeing funds availability, the intermediary has an incentive to efficiently monitor the borrowers, produce information and signal its credibility, and specialize in credit evaluation. OBS banking activities thus represent substitute methods for allocating credit with complementaries in production. The risk-return trade- off between saving information services and warehousing assets will induce a bank to divide its business between both balance and off-balance sheet financial activities. Therefore, OBS activities do not affect fundamental business risk of banking firms. Because part of business risk is diversifiable, the remaining market risk is also unaffected by OBS activities. The diversification hypothesis implies that banks engage in OBS activities to diversify its asset portfolio in order to achieve within firm diversification and to avoid the wrath of disappointed bank shareholders [see Diamond (1984), Pavel (1987, 1988)]. Within-firm bank risk is reduced by low correlation of OBS activities with other bank asset activities. Mlarket risk of OBS activities is determined by diversification within banking firm and by stockholders. Therefore, part of diversifiable risk of bank's total risk is 
eliminated by bank's within-firm diversification potential of 0BS activities, and part is eliminated by diversified stockholders in their own portfolios. This hypothesis suggests a negative relationship between total bank risk and OBS activities.

The Leverage Hypothesis states that fixed rate deposit insurance together with capital requirements provide incentives to increase financial leverage through the issuance of OBS activities that are not subject to capital requirements. By increasing financial leverage in this way, a bank can enhance whatever subsidies it receives from deposit insurance. This hypothesis thus predicts a positive relationship between total bank risk and OBS activities. [see Pyle (1985), Benveniste and Berger (1986)].

The Collaterization and Underinvestment Hypothesis states that SLCs and loan sales, two OBS items, are substitutes for collaterized debt claims because banks are prohibited from issuing collaterized deposits. Loan sales and SLCs have payoff characteristics similar to secured debt. Like secured debt, these off-balance activities permit banks to sell a portion of cash-flors associated with new investment opportunities. The ability to engage in off-balance sheet activities, therefore, permits banks to invest in loans with positive net present value that they would pass up if restricted to deposit financing. Capital requirements, which limit bank leverage, intensifies the underinvestment problem by restricting a bank's ability to offset reductions in bank asset risk with increases in financial leverage. Fixed rate deposit insurance premium increases the underinvestment problem because rates paid on bank deposits do not reflect the marginal contribution of a ner investment to the risk of bank's portfolio of assets. The underinvestment problem is likely to be greater if the bank has riskier deposits and higher capital requirements. Therefore, the 
amount of SLCs and Loan Sales are expected to be positively related to riskiness of banks [see James (1988)].

The empirical literature on the "market discipline" of OBS banking activities tests for the existence of market sensitivity to bank risk by regressing the relative cost of bank funds on balance-sheet and off-balance sheet and/or income statement measures of risk, return and market position. The basic issue is whether the measures of bank risk are significantly related to movements in bank liability or equity prices. If significant relationships are found, then "market discipline" is said to exist.

The empirical evidence on the existence of "market discipline" of OBS banking activities in inconclusive. The earliest work by Pettway (1976, 1976a), Beighly, Boyd and Jacobs (1975), Jahankhani and Lynge (1980) examined bank financial policies on equity and liability prices.

Pettray investigated the impact of the bank's capital position on (1) the risk premium of the bank's capital notes, (2) the bank's beta and (3) the price-earnings (P/E) ratio, during the 1971-74 period. This cross-section study indicated that dividend yield, payout ratio and earnings growth are significant in explaining the variability of price-earnings ratios. He also found no apparent relationship between beta and these accounting variables for large banks prior to 1974 and slightly significant inverse relationship after 1974 .

A study by Beighly, Boyd and Jacobs (1975) examined the relationship between financial leverage and stock price for 113 bank holding companies for the periods 1972 through 1974. They used the average level of the common stock price (three month average) as a dependent variable. They found that dividends, earnings growth, firm size and loan loss rate were the most important determinants of the market prices of bank equities. They also found that for 
the given sample of bank holding companies, the higher a bank's degree of financial leverage at a point in time, the lower is the bank's stock price (after controlling for bank size, earnings growth, dividends and loan losses).

Jahankhani and Lynge (1980) investigated the relationship between financial policies of commercial banks and two market determined measures of risk. Financial policies are proxied by average balance sheet and income statement data over the period 1972-76 for 95 commercial banks and bank holding companies. Accounting data measures of financial leverage, liquidity, dividend payout ratio, loan loss experience and variability in earnings and deposits are used. These are related to a measure of systematic risk (beta) and total risk (standard deviation of equity return), also calculated for the same five-year period. Bivariate and multivariate relationships are examined. As independent variables used to explain beta, the coefficients of the dividend payout ratio, variability of deposits and the loan to deposit ratio are significant. In explaining total risk the coefficients of the dividend payout ratio, a financial leverage measure, variability of deposits and earnings, a loan loss measure and a liquidity measure are all significant.

Baer and Brewer (1986) regressed CD rates over quarterly measures of bank accounting risk variables for a sample of 37 banks over the time period 1979-82. They present evidence that bank CD rates are strongly affected by accounting based measures of bank risk-taking. The market for large, uninsured CDs helps discipline bank risk-taking by penalizing risky banks with a higher CD risk premium. Baer and Brewer study (1985) supports the conclusions of another study by Hannan and Hanweck (1988) that employs survey data on CD rates for five different maturities and finds that CD risk premiums increase with both the ratio of risky assets to capital and uncertainty regarding bank returns on assets . 
Avery, Belton, and Goldberg (1988) conducted a cross-section study of subordinated debt pricing for both 1983 and 1984. Subordinated debt is junior to uninsured CDs so that its pricing ought to show clear responses to risk measures. However, examining the spread over the comparable treasury yields these authors were unable to demonstrate the effect of any balance sheet or income statement data on bank costs. They also conclude that implicit insurance of a bank debt is not a consistent explanation for the lack of correlation between default premia and on-balance accounting measures of risk because there is significant variation of risk premia across banks in the sample.

Although none of these studies include OBS banking risk variables, these studies show the appropriateness of accounting-based risk models in analyzing the impact of OBS banking activities on bank risk measures.

Goldberg and Lloyd-Davies (1985) explain CD rates as function of the general level of interest rates and various measures of bank risk including SLCs. Accounting risk variables used are loan-loss reserve position, net income ratio, interest sensitive liabilities, capital over risky assets and SLCs over risky assets. The effects of bank's SLC exposure on CD rate is treated as having two components: a leverage effect (the ratio of bank capital to risky assets including loans and SLCs) and a credit quality effect (the ratio of SLCs to risky assets, to allow for differences in credit quality of the loan and SLC portfolios). Based on this model, they found that CD rates rose with increasing leverage and fell with increases in SLCs as a proportion of total risky assets. Since these tro factors tend to cancel each other, the net effect on bank risk of an increase in bank's SLC exposure apparently is negligible. The inclusion of SLC as a ratio of total risky assets did not improve the explanatory power of this model. They explain this to be due to the capital/loan variable that 
impounds both the beneficial impacts of SLCs on credit quality and the adverse impact of SLCs on capital exposure. Their study also found that, despite higher credit quality, increasing SLCs did not reduce bank risk.

Brewer, Koppenhaver and Wilson (1986) use an empirical method based on a version of CAPH that estimates systematic risk associated with various components of a bank's income statement, balance sheet and off-balance sheet activities. In a time-series, cross-sectional analysis of 63 bank holding companies for 1983-84 with a two factor CAPII, it is found that equity market prices SLCs but not loan commitments or commercial letters of credit. Horeover, SLCs are priced as risk-reducing, not risk-increasing activity of banks by well-diversified shareholders. The second factor used in CAPII is a value-weighted banking industry stock market index. The regulatory implication of this study is that (1) loan commitments and commercial letters of credit are not perceived as risk-increasing activities for banks and that their inclusion in the recently proposed risk-based capital requirement is wrong, and (2) a tax imposition in the form of capital requirement on SLCs, that disciplines bank management and is perceived by the equity market as risk-reducing, is inappropriate.

Lynge and Lee (1987) used accounting-based risk forecasting models to investigate the impact of OBS items on both equity risk and systematic risk for large commercial banks for the time period 1984-85 for a sample of 81 large banks. The estimated coefficients of independent variables incorporating various aspects of OBS positions are statistically significant in a model explaining total equity risk, but not significant in a model explaining systematic risk. The negative coefficients of OBS variables in a model explaining total equity risk is attributed to diversification potential of these banking activities. 
Pavel (1988) analyzes three reasons for loan sales -- funding, diversification, and capital requirement -- by empirically testing their relevance to and their implications for bank risk. The data set used in the study contains 117 bank holding companies during 1984 and 1985. This research shows, on average, loan sales have little impact on bank risk. Funding, diversification, and regulation all seem to be factors motivating loan sales, but the use of loan sales to increase diversification or avoid regulation does not significantly affect bank risk any more than other means to achieve these ends. Capital requirements do not seem to play as large a role in loan sales as previous research indicated. One explanation is that loan sales made unprofitable by capital requirement are probably sold immediately and, therefore, have no impact on a bank's portfolio.

Avery and Berger (1988) regressed measures of the current performance of a bank's portfolio -- the ratio of non-performing loans to total loans, the ratio of net chargeoffs to total loan and ratio of net income to total loans -against measures of the bank's OBS activities to investigate the risk potential of these activities. They used two different data sets. The first is collected from Federal Reserve's Commitment Survey and includes a panel of individual bank call and commitment data ranging from 1973 to 1987. The second data set consists of semi-annual call Report data on 11 OBS activities and bank performance and control variables collected for all banks over 100 million dollars of gross assets from 1985 to 1987 . Their research suggests that among major OBS activities, SLCs are associated with poor bank performance but loan commitments are associated with better bank performance. No statistically significant relationship was found between bank performance and other OBS activities. They conclude that risk-based capital proposal may be appropriate 
for SLCs but may be unwarranted for loan commitments because of their risk-reducing potential.

James (1988) tests two hypotheses about loan sales and SLCs. The first hypothesis is that depositors and the FDIC are not necessarily worse off by these two OBS banking activities. The second hypothesis is that since the underinvestment problem is likely to be more severe the riskier the bank's existing deposits and the greater the amount of equity capital a bank is required to use for new loans, the volume of loan sales and SLCs are expected to be greater the riskier the bank and for banks with binding capital requirement. An analysis of CD rates of 58 banks over the period 1984 through 1986 reveals no statistically significant relation between the risk premium on uninsured deposits and the amount of SLCs outstanding or loan sales. Moreover, the volume of SLCs relative to bank capital is found to be positively related to balance sheet measures of bank risk as well as financial leverage.

This paper employs an extended data set ranging from 1984 to 1988 and examines risk behavior of all 19 OBS items from Call and Income Reports of the FDIC tapes. This research sheds further light on "market discipline" of OBS banking risk by regressing OBS items against default-risk premia borne by subordinated debtholders in addition to equity and systematic risk borne by stockholders .

III. The Relationship of OBS Banking Activities to Risk-Premia Required on Bank Subordinated Debt

\subsection{Introduction}

Subordinated debtholders are subject to a larger risk of loss than uninsured depositors. Market discipline by uninsured depositors appears limited 
by (a) these depositors' ability to withdraw funds quickly once a problem situation becomes apparent, and (b) by the fact that they typically receive de facto insurance coverage when the FDIC uses the method of purchase and assumption to resolve a problem situation. In contrast, subordinated debt can be a source of funding that cannot be withdrawn during adversity and is generally not assumed by the purchasing bank in a purchase and assumption transaction. Thus, subordinated debtholders are generally subject to greater risk than uninsured depositors.

The potential of subordinated debt to enhance market discipline is examined empirically by analyzing the interest rate spread between subordinated debt and treasury securities. This spread, or default-risk premia, is modeled as a function of various on-balance and off-balance measures of risk.

\subsection{Empirical Model}

The following risk-premia model is estimated over cross-section and time-series data using the generalized least squares (GLS) technique to examine the risk-behavior of OBS banking activities. The expected signs of partial derivatives appear on each independent variable:

$$
R-R_{f}=f(\stackrel{-}{\mathrm{OBS}}, \stackrel{+}{\mathrm{LEV}}, \stackrel{-}{\mathrm{DIV}}, \stackrel{+}{\mathrm{ALOSS}}, \stackrel{+}{\mathrm{AGAP}}, \stackrel{\bar{A}}{\mathrm{AIZE}}, \stackrel{-}{\mathrm{POOR}})
$$

where

$R-R_{f}=$ Default-risk premia;

OBS = Seven off-balance sheet variables constructed from 19 items included in the RC-L schedule of the FDIC tapes;

LEV = ratio of total liabilities over total assets;

DIV = an index of diversification (the higher the diversification index is, the higher the level of diversification is in the loan portfolio); 


$$
\begin{aligned}
& \text { ALOSS = ratio of loan loss reserves over total assets; } \\
& \text { AGAP = ratio of net position (total market rate assets minus market }
\end{aligned}
$$

rate liabilities) to total assets;

ASIZE = logarithm of assets of banks;

$\mathrm{POR}=$ cash dividends over net income.

Leverage (LEV), diversification (DIV), Credit risk (ALOSS), Interest rate risk (AGAP), Operating risk (ASIZE) and dividend payout (POR) are all on-balance measures of risk, and have been used extensively in "market-discipline" studies of bank financial policies. These variables have been scaled down by size in order to avoid heteroskedasticity problem.

Two main effects of OBS banking activities on risk, namely diversification and leverage effects, are rationalized in theoretical literature. However, on a priori, it is difficult to say which effect dominates. The negative sign of DIV variable indicates that diversification by bank loan portfolio reduces total risk. The positive sign of LEV variable indicates that leverage ratios of banks increase total risk. In addition, the negative signs of OBS variables in equation (1) imply that, after controlling for on-balance leverage and diversification effects, risk-reducing diversification effect of OBS activities dominates risk-increasing effects of OBS activities.

Table 1 reports 19 OBS activigties from the PC-L schedule of bank call and income reports. Seven off-balance variables have been constructed from these 19 OBS items.

\subsection{Data Analysis}

This research focuses on the 100 largest U.S. banks and BHCs, as these are only ones with publicly traded subordinated debt and debentures. Data on yield measures were gathered on all BHC for bank subordinated debt, debentures and 
capital notes which were publicly traded in the NYSE, ANEX, NASDAO with quoted sale and bid prices from Moody's and Standard and Poor's bond manuals as of year ends 1984 through 1988. To make each BHC debt issue as homogeneous as possible, all zero coupon issues and floating rate issues were dropped from the sample. This produced 171 issues for $50 \mathrm{BHCs}$ in 1984, 137 issues for $49 \mathrm{BHCs}$ in 1985, 160 issues for $48 \mathrm{BHCs}$ in 1986, 174 issues for $43 \mathrm{BHCs}$ in 1987 and 223 issues for 49 banks in 1988. Virtually all of these bonds were issued against the BHCs rather than the bank. There was a fair amount of heterogeneity in terms of maturity, coupons and issue size. Acquisitions or name changes of banks have been confirmed from Moody's Bank and Finance Manual in order to maintain continuity in data collection.

The risk-free rates of Treasury Securities identical in maturity to each debt issue were collected from Iloody's Bond Record. Yields of multiple issues of a bank's subordinated debts are aggregated to calculate an average yield. Risk-premiums are calculated by simply subtracting risk-free rates of identical maturity from the yield measure. The risk-premium used in this study is the average premium of all outstanding issues for each BHC for each year. The on-balance and off-balance measures of risk are constructed as defined earlier, from variables available in the FDIC Call and Income Report for the years 1984 through 1988. The risk-premia of each BHC is matched against on-balance and off-balance measures of risk, and this resulted in a final sample of 32 bank and BHCs for each year. These risk-premia are then used as the dependent variables in regression analysis of on-balance and off-balance measures of bank risk.

\subsection{Analysis of Results}

Table 3 provides the coefficient estimates of a basic risk-premia model. Seven equations were estimated, one for each off-balance sheet group, using 
pooled cross-section and time-series data for 32 banks and bank-holding companies over the years 1984-88. All off-balance sheet items have expected negative signs. Three of these coefficients are significant at the $1 \%$ level (APART, ACLC, AOBS), two are significant at the $5 \%$ level (A0B, ASWAP), and one is significant at the 10\% level (ACOMM). The coefficient of SLC is not significantly different from zero. This result is consistent with the results of Goldberg and Lloyd-Davies (1985) for Standby Letters of Credit (SLCs) but extends these results to other categories of OBS items.

Variations in the risk-premia on uninsured bank debt are significantly correlated with off-balance sheet variables, suggesting the presence of a "market discipline." Moreover, bank liability holders view OBS variables as risk-reducing. The pricing signal that the banking industry receives from the subordinated debt market appears to be at odds with the regulatory prescription about off-balance sheet variables. Those prescriptions require certain OBS items be included in the risk-based capital requirement. The risk-reducing potential of off-balance sheet variables indicates that bank regulators may be overly concerned about these banking activities and should not penalize banks for these OBS activities by requiring additional capital.

The on-balance measures of risk, generally, obtain their expected signs. Both leverage and diversification (LEV and DIV) variables have the expected signs and are significant at the $5 \%$ level. The significant negative coefficients of OBS items along with expected signs of leverage and diversification (LEV and DIV) variables also suggest that risk-reducing diversification impacts of OBS activities dominate their risk-increasing impacts. The interest rate risk (AGAP) is positive and significant at the $10 \%$ level. The credit risk variable (ALOSS) is, however, significantly negative. 
Here multicollinearity between credit risk and interest rate risk (ALOSS and AGAP) may be the cause of this perverse sign. The dividend payout ratio (POR) variable has an insignificant positive coefficient. The size (ASIZE) variable has, in general, negative coefficients and, in one case, is significant at the 1\% level. These results are consistent with studies by Pettway (1976), Pavel and Philis (1987) and Koppenhaver (1987).

IV. The Relationship of OBS Banking Activities to Equity Risk and Systematic Risk of Large Bank and Bank-Ilolding Companies

\subsection{Introduction}

In order to examine whether equity prices reflect OBS banking risk, both total risk and systematic risk have been regressed over on-balance and off-balance measures of risk. Total risk is proxied by standard deviation of equity return and systematic risk is proxied by market beta. Although the CAPII is based upon ex ante observations the suggested model uses primarily ex post data. The market beta is determined from past prices and, therefore, is only an estimate of historical beta.

\subsection{Empirical Model}

The following two models are estimated over cross-section and time-series data employing a generalized least square (GLS) technique. The expected signs of partial derivatives appear on each independent variable:

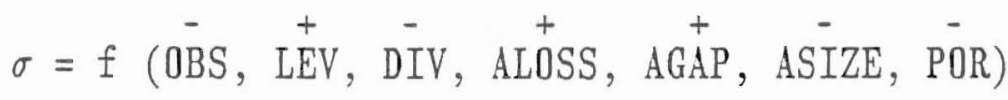

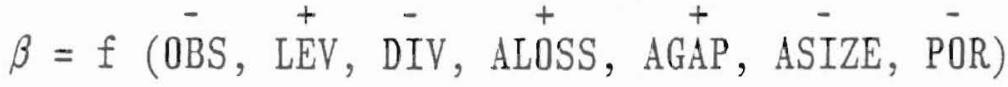

These two models determine the relationship between the same on-balance and off-balance sheet variables as in risk-premia model, except that the bank's equity risk and systematic risk become the dependent variables. 
Theory suggests that OBS activities provide diversification benefits to bank stockholders, and at the same time, increase financial risk by augmenting leverage. It is known that diversification potential will reduce diversifiable risk and leverage potential will increase financial risk of total equity risk respectively. Which effect dominates remains an empirical question. If OBS activities are rationalized as natural banking activity, they are not expected to affect non-diversifiable systematic risk as measured by beta.

The negative sign of DIV variable indicates that diversification by bank loan portfolio reduces total risk. The positive sign of LEV variable indicates that leverage ratios of banks increase total risk. In addition, the negative. signs of OBS variables in equation (2) imply that, after controlling for on-balance leverage and diversification effects, risk-reducing diversification effect of OBS activities dominates risk-increasing effects of OBS activities.

4.3 Data Analysis

Extensive data on bank off-balance sheet activities (OBS) are available beginning in 1984. The initial sample utilized in this study consists of the 100 largest banks based on asset size which have continuous data over the years 1984 through 1988. Market values of equity (EQUTTY) for each bank or bank holding company are collected from COMPUSTAT yearly tapes. Daily bank stock returns and market returns are gathered from the CRSP and the NASDAD daily tapes. Data on off-balance sheet items are taken from the FDIC Call and Income Reports for the lead bank of the holding company. The sample is restricted to those bank holding companies (BHC) whose lead bank accounts for the majority of consolidated holding company assets. The accounting risk variables defined in the previous section (LEV, DIV, AGAP, ALOSS, POR and ASIZE) are constructed from data collected from the FDIC yearly tapes. Data from the FDIC tapes, the 
COMPUSTAT tapes, the CRSP tapes and the NASDAQ tapes are merged together, and this resulted in a final sample of 32 banks and bank holding companies for 1984 through 1988. The relative size of market risk measures, accounting risk measures and OBS variables are shown in Table 2 .

Equity risk is proxied by the standard deviation of equity return. SIGWAE is the annualized standard deviation of daily equity return. SIGMAEs are calculated for those bank holding companies for which 200 or more trading days are available on CRSP and NASDAQ tapes. It can be noted that only 63 bank holding companies have equity return available on CRSP tape and 82 BHCs have similar data available from the NASDAQ tape.

BETAs are calculated from daily equity returns for each bank holding company for which 200 or more trading days are available from the CRSP and the NASDAQ TAPES. The standard market model is used in this study to estimate betas and the market index used is equally-weighted market index. Hence, these beta estimates are different from Scholes-Williams betas reported in the new CRSP tapes. Scholes and Williams (1977) calculated betas from nonsynchronous data using a methodology different from market model methodology.

4.4 Analysis of Results

Table 4 presents estimates of the explanatory variables using standard deviation of equity return (SIGMAE) as the dependent variable. Off-balance sheet items constitute a heterogeneous collection of participations, commitments, and other arrangements. Therefore, it is difficult to represent the influence of these items in any simple way. The off-balance sheet variables are grouped into seven classes according to their similar characteristics. All off-balance sheet variables possess negative coefficients. One of these coefficients is significant at the $1 \%$ level (ASLC), four are significant at the 
$5 \%$ level (AOB, ACOMA, AACLC, AOBS) and one is significant at the $1 \%$ level (ASWAP). The coefficient of APART is not significantly different from zero. These results suggest that at least some of the off-balance sheet variables are risk-reducing. These results support the findings of Lynge and Lee (1987) that off-balance sheet items reduce total risk.

The hypothesis that risk-reducing diversification potential of OBS items dominates the risk-increasing potential of OBS items can be tested by comparing the estimated coefficient signs of leverage and diversification (LEV and DIV) variables. The significant negative sign of diversification coefficient (DIV) indicates an inverse relationship between diversification and risk. Therefore, banks can achieve higher level of diversification by engaging in off-balance sheet activities and consequently reduce risk. The coefficients of LEV and DIV possess expected signs. The significant positive coefficient of leverage (LEV) variable indicates a direct relationship between leverage employed and risk. Therefore, banks can increase leverage by engaging in off-balance sheet activities and consequently increase risk. Given that leverage and diversification variables are on-balance sheet measures, the significant negative coefficients of some off-balance sheet items, therefore, imply that diversification potential of OBS items dominates leverage potential after accounting for such effects by on-balance sheet variables, and hence result in an overall reduction of risk.

The credit risk and dividend payout ratio (ALOSS and POR) variables have the expected positive and negative signs respectively, and are statistically significant. The positive coefficient of credit risk (ALOSS) variable indicates a direct relationship between customer default-risk and overall riskiness of banks. The negative coefficient of dividend payout ratio (POR) variable implies 
an inverse relationship betiveen bank risk and dividend payout ratio. The size (ASIZE) variable has an unexpected positive coefficient; but here size (ASIZE) is also highly correlated with off-balance measures of risk, perhaps pointing towards a simultaneity between size and off-balance sheet items. These results are, however, consistent with previous studies of market-determined and accounting-determined measures of bank risk variables (Pettway, 1976).

Table 5 presents estimates of explanatory variables using BETA as the dependent variable. The estimated coefficients of all OBS items have expected negative signs, and all but one are not statistically significant. These results suggest that most OBS activities have no effect on systematic bank risk. The results are consistent with Pettway (1976) and Lynge and Lee (1987). Standby Letters of Credit (ASLC) is significantly negative at the $5 \%$ level, implying that well-diversified investors price this banking activity as risk-reducing. This result validates a similar finding by Brewer, Koppenhaver and Wilson (1986) that equity market prices Standby Letters of Credit (ASLC) as risk reducing.

The coefficients on the on-balance measures of risk have expected signs. Leverage (LEV) is significantly positive at the $1 \%$ level and Diversification (DIV) is significantly negative also at the $1 \%$ level. Credit Risk (ALOSS) is also significantly positive at the $1 \%$ level. Dividend payout ratio (P0R) is not statistically significant. Although interest rate risk and size (GAP and ASIZE) have the wrong signs, they are not statistically significant.

Models using the total risk (SIGIAE) as the dependent variables have higher average $R^{2}$ compared to models using systematic risk (BETA) as the dependent variables (.18 versus .14). The fact that on-balance and off-balance measures of risk explain a larger portion of total risk than systematic risk is not 
surprising. Total risk includes both systematic risk and specific risk. Certain diversifiable accounting measures of risk such as credit risk (ALOSS) are expected to affect mostly specific risk rather than systematic risk.

\section{v. Conclusions and Policy Implications}

The primary purpose of this paper has been to examine whether "market discipline" exists for 0BS banking risk. Default-risk premia, total equity risk and systematic beta risk have been regressed on various on-balance accounting risk variables and off-balance sheet activities.

A pooled cross-section and time-series model, instead of simple OLS, was employed to perform the econometric analysis for two reasons. First, cross-section or time-series data alone (32 cross-sections and 5 time-periods) are not sufficient to extract enough degrees of freedom in regression analysis. Second, cross-sections and time-series relationships of OBS banking decisions are better captured by a pooled cross-section and time-series model.

The major empirical findings of this study can be summarized as follows. First, test results support the hypothesis that risk-reducing diversification effects of OBS banking items dominate risk increasing effects of 0BS banking items, thus reducing overall riskiness of banks. Second, the results also validate the hypothesis that OBS banking items do not affect systematic risk. Only Standby Letters of Credit reduce systematic risk. Third, all but one (APART) off-balance measures of risk in this study are risk-reducing.

Fourth, the explanatory powers of the models are improved significantly when equity variances, instead of market betas, are used to proxy for bank risk. This is evidenced by significant increase in $R^{2}$. Fifth, this study finds the presence of a "market discipline" of OBS banking activities. The market 
participants, both stockholders and subordinated debtholders, price OBS activities as risk-reducing. Sixth, several on-balance measures of accounting risk also show statistically significant correlations with market measures of risk. Finally, pooled cross-section and time-series analysis of OBS banking risk provides better coefficient estimates (increased t-statistics) and increases the statistical significance of models (increased F-statistics).

The existing policy proposal to regulate OBS banking risk by bringing them into a risk-based capital requirement can be analyzed in the light of empirical findings of this research. The results indicate that off-balance sheet activities, in general, reduce total risk, but do not affect systematic risk, implying that off-balance sheet risk is not a concern of well-diversified stockholders. While bank regulators are concerned with total risk and the probability of bank failures, the risk reducing potential of OBS activities indicates that additional capital requirement of OBS banking activities will penalize large banks.

There is clear evidence of a "market discipline" of OBS banking risk. Harket participants price these OBS activities as risk-reducing. Therefore, regulatory interference in the form of additional capital requirement of OBS activities will create distortions in the financial intermediation market. 


\section{REFERENCES}

1. Avery, Robert B., Terrence M. Belton, and Michael A. Goldberg (1988), "Harket Discipline in Regulating Bank Risk: New Evidence from the Capital Markets," Journal of Monev. Credit and Banking (June).

2. Avery, Robert B. and Allen N. Berger (1988), "Risk-based Capital and Off-Balance Activities," Proceedings of a Conference on Bank Structure and Competition, Federal Reserve Bank of Chicago, pp. 261-287.

3. Baer, Herbert and Elijah Brewer (1986), "Uninsured Deposits as a Source of Harket Discipline: Some New Evidence," Economic Perspectives

(September/October), Federal Reserve Bank of Chicago, pp. 23-31.

4. Beighley, H. Prescott, John H. Boyd, and Donald P. Jacobs (1975), "Bank Equities and Investor Risk Perspectives: Some Entailments to Capital Adequacy Regulation," Journal of Bank Research, Autumn.

5. Benveniste, L. and Allen N. Berger (1986), "An Empirical Analysis of Standby Letters of Credit," Proceedings of a Conference on Bank Structure and Competition, Federal Reserve Bank of Chicago, pp. 387-412.

6. Brewer, E., G. Koppenhaver, and D. Wilson (1986), "The Harket Perception of Bank Off-Balance Sheet Activities," Proceedings of a Conference on Bank Structure and Competition, Federal Reserve Bank of Chicago, pp. $\frac{412-436 .}{2}$

7. Chang, Hui-Shyong and Cheng-Few Lee, "Using Pooled Time-Series and Cross-Section Data to Test the Firm and Time Effects in Financial Analyses," Journal of Financial and Duantitative Analvsis, 12 (September 1977), pp. 457-471.

8. Cramer, Robert H. and Robert J. Rogowski (1985), "Risk Premia on Negotiable Certificates of Deposit and the Continental Illinois Bank Crisis," mimeo.

9. Diamond, Douglas, "Financial Intermediation and Delegated Monitoring," Reviev of Economic Studies (1984), pp. 393-414.

10. Giddy, Ian (1985), "Regulation of Off-Balance Sheet Banking," The Search for Financial Stabilitv: The Past Fiftv Years, Federal Reserve Bank of San Francisco, pp. 165-177.

11. Goldberg, Michael A. and Peter R. Lloyd-Davies (1985), "Standby Letters of Credit: Are Banks Overextending Themselves," Journal of Bank Research 16 (Spring), pp. 29-39.

12. Hannan, Timothy and Gerald Hanweck (1988), "Bank Insolvency Risk and the Mlarket for Large Certificates of Deposits," Journal of Monev. Credit and Banking (Ifay).

13. Jahankhani, Ali and Horgan J. Lynge (1980), "Commercial Bank Financial Policies and Their Impact on Market-Determined Risk," Journal of Bank Research, 11:3 (Autumn), pp. 169-178. 
14. James, Christopher (1988), "The use of Loan Sales and Standby Letters of Credit by Commercial Banks," Jomrnal of llonetarv Economics, vol. 22, pp. $395-422$.

15. Koppenhaver, G.D. (1987), "Standby Letters of Credit," Economic

Perspectives, Federal Reserve Bank of Chicago, July-August, pp. 28-38.

16. Lynge, Morgan and Cheng-Few Lee (1987), "Total Risk, Systematic Risk, and Off-Balance Sheet Risk for Large Commercial Banks," WP, University of Illinois at Urbana-Champaign.

17. Pavel, Christine (1988), "Loan Sales Have Little Effect on Bank Risk," Economic Perspectives, Federal Reserve Bank of Chicago, 12, pp. 23-31.

18. Pavel, Christine and David Philis (1987), "Why Commercial Banks Sell Loans: An Empirical Analysis," Economic Perspectives, Federal Reserve Bank of Chicago, 11, pp. 3-14.

19. Pettway, Richard H. (1976), "Harket Tests of Capital Adequacy of Large Commercial Banks," Journal of Finance (June).

20. (1976a), "The Effects of Large Bank Failures Upon Investors' Risk Cognizance in the Commercial Banking Industry," Journal of Financial and Onantitative Analvsis (September).

21. Pyle, D., "Regulation of Off-Balance Sheet Banking Discussion," The Search for Financial Stabilitv: The Past Fiftv Years, Federal Reserve Bank of San Francisco, 1985, pp. 185-189.

22. Scholes, Hyron and Joseph Williams (1977), "Estimating Betas from Nonsynchronous Data," Journal of Financial Economics, vol. 5, pp. 309-327. 
TABLE 1

OBS ITEMS (SCIEDULE RC-L OFF-BALANCE SILET VARIABLES)

1. Securities borrowed

2. Securities lent

3. Commitments to purchase when issued securities

4. Commitments to see when issued securities

5. Notational value of interest rate swaps

6. SLC to U.S. addresses

7. SLC to non U.S. addresses

8. SLC participated to others

9. Commercial letters of credit

10. Commitments to purchase foreign currencies

11. Unused loan commitments

12. Commitments to purchase futures and forward contracts

13. Commitments to sell futures and forward contracts

14. Obligation to purchase under option contracts

15. Obligations to sell under optons contract

16. Participations in acceptances conveyed to others

17. Participations in acceptances conveyed from others

18. Other significant commitments or contingencies

19. Loan sold or participated to others

The off-balance sheet variables consist of the following items:

$\mathrm{OB}$

COMAI $=12+13+14+15+18$

PART $=8+16+17+19$

SWAP $\quad=5$

$\mathrm{SLC} \quad=6+7-8$

CLC $\quad=9$

OBS $=$ OB + COMH + PART + SWAP + SLC + CLC 
TABLE 2

SUMMARY STATISTICS FOR ACCOUNTING RISK VARIABLES, OFF-BALANCE SIIEET VARIABLES AND MARKET MEASURES OF RISK VARIABLES ${ }^{a}$

\begin{tabular}{|c|c|c|c|}
\hline$\underline{\text { Variable }}$ & $\underline{\text { Svmbol }}$ & Mean & $\begin{array}{l}\text { Standard } \\
\text { Deviation }\end{array}$ \\
\hline Risk Premium & RPRH & .01500 & .00665 \\
\hline Systematic Risk & BETA & .85337 & .40162 \\
\hline Equity Risk & SIGHAE & .01828 & .01124 \\
\hline Off-balance sheet groups & $\mathrm{AOB}$ & .97779 & .94551 \\
\hline Commitments & ACOAMI & .16469 & .24067 \\
\hline Participations & APART & .09618 & .27160 \\
\hline National Value of Swaps & ASWAP & .32129 & .52079 \\
\hline Commercial Letters of Credit & ACLC & .01523 & .01095 \\
\hline Standby Letters of Credit & ASLC & .07394 & .04687 \\
\hline Total Off-Balance Items & AOBS & 1.58013 & 1.69662 \\
\hline Financial Leverage & LEV & .94938 & .01317 \\
\hline Diversification Index & DIV & 1.74527 & .67445 \\
\hline Credit Risk & ALOSS & .01341 & .00956 \\
\hline Interest Rate Risk & AGAP & .05955 & .13878 \\
\hline Dividend Payout Ratio & POR & .50910 & .74757 \\
\hline Logarithm of Assets & ASIZE & 16.65717 & .99929 \\
\hline
\end{tabular}

a: For a sample of 32 commercial banks and bank holding companies over 1984- 1988 periods. 


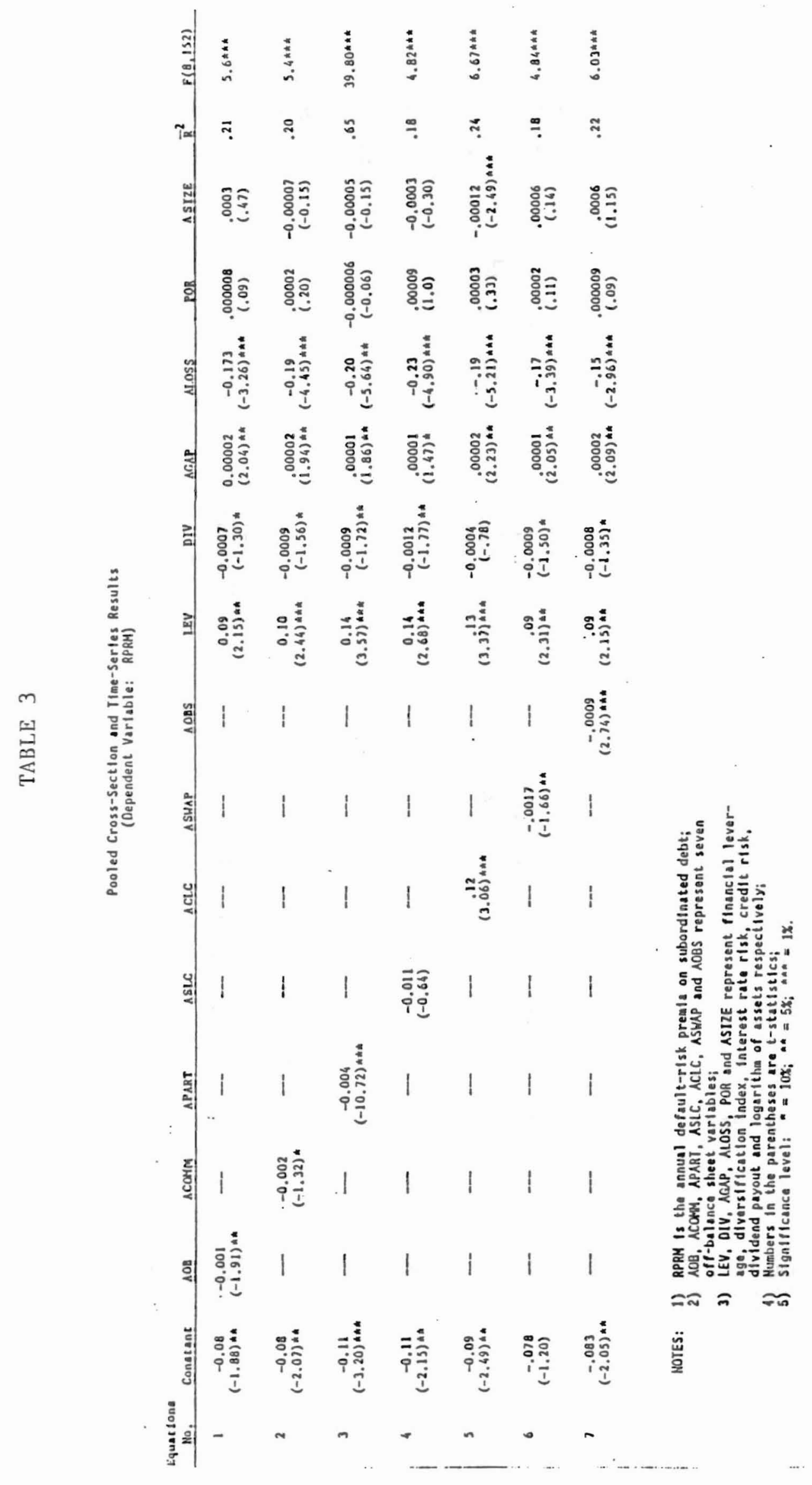


TABLE 4

Pooled Cross-Sectlon and Time-Serles Results (Dependent Varlable: SIGMAE)

\begin{tabular}{|c|c|c|c|c|c|c|c|c|c|c|c|c|c|c|c|c|}
\hline $\begin{array}{l}\text { Equat tons } \\
\text { No, } \\
\end{array}$ & Conatane & $\triangle 0 \mathrm{BB}$ & $\triangle \mathrm{COHM}$ & APART & ASLC & AcLE & ASHAR & Aoss & LEV & Div & SEAP & Noss & $\mathrm{POB}$ & ASIZE & $\bar{R}^{2}$ & $F(8,152)$ \\
\hline 1 & $(2.31) \star k$ & $\begin{array}{c}-.0015 \\
(-2.06)^{\mathrm{kt}}\end{array}$ & -- & - & - & -- & - & - & $(2.74)^{\text {Anat }}$ & $(-0.0017)$ & $\frac{-.00001}{(-1.42)^{k}}$ & $(5.40)^{34 k}$ & $(-i .47)^{4}$ & $\frac{.0018}{(2.49)^{* * \hbar *}}$ & .27 & $8.12 \mathrm{kAk}$ \\
\hline 2 & $(2.90)^{\text {\#AA }}$ & - & $\begin{array}{l}-.005 \\
(-1.97)^{n k}\end{array}$ & - & -- & - & - & - & $(3.13)^{14 A n}$ & $\begin{array}{l}-.0015 \\
(-1.61)^{k}\end{array}$ & $\begin{array}{r}-.00001 \\
(-1.80)^{a}\end{array}$ & $(5 . i 7)^{31}$ & $\begin{array}{l}-.00008 \\
(-2.48) \text { AAth }\end{array}$ & $\begin{array}{l}(2.0014 \\
(2.10) \star \hbar k\end{array}$ & .30 & $9.28 \mathrm{AAn}$ \\
\hline 3 & $\frac{.12}{(2.53)^{\text {AAA }}}$ & -- & - & $(-i .11)$ & - & - & - & - & $(2.67)^{\text {AaA }}$ & $\begin{array}{l}-.0015 \\
(-i .53) \star\end{array}$ & $\frac{-.00001 \hbar}{(-1.55)^{\star n}}$ & $(4.85)^{28 A A}$ & $\begin{array}{l}-.00009 \\
(-2.01)^{\wedge A}\end{array}$ & (2.53) AnA A A & .23 & $6.47 \mathrm{AkA}$ \\
\hline 4 & $\begin{array}{l}.052 \\
(.95)\end{array}$ & - & - & -- & $\begin{array}{c}-0.07 \\
(-4.15)^{* A A \hbar}\end{array}$ & - & $\cdots$ & -- & $(1.67)^{.086}$ & $\begin{array}{l}-.0022 \\
(-2.32)^{\text {\#th }}\end{array}$ & $\begin{array}{l}-.00001 \\
(-2.07)^{\text {An }}\end{array}$ & $(5.34)^{\star A n k}$ & $\begin{array}{l}-.00004 \\
(-1.57)^{4}\end{array}$ & ${ }^{00033}$ & .35 & ill.74. AhA \\
\hline 5 & $\frac{.10}{(2.30)^{4 k}}$ & - & - & - & - & $(-1.065)$ & -- & - & $\frac{.11}{(2.48) A A A B}$ & $\begin{array}{l}-.0009 \\
(-.95)\end{array}$ & $\begin{array}{l}-.00001 \\
(-1.66)^{* A}\end{array}$ & $(4.66)^{\text {hth }}$ & $\begin{array}{l}-.00001 \\
(-2.76) \text { A }\end{array}$ & $(1.79)^{.001}$ & .27 & $7.97 \mathrm{AkA}$ \\
\hline 6 & $(2.96)$ AAn & $\cdots$ & - & - & -- & -- & $\frac{-.0026}{(-i .56) n}$ & - & $\begin{array}{l}15 \\
(3.10)_{\text {AaA }}\end{array}$ & )$_{(-i .90)^{\text {at a }}}^{-0018}$ & $\begin{array}{r}-.00001 \\
(-1.60)^{\star}\end{array}$ & $\left(4 . i_{8}^{33}\right)^{\text {AAA }}$ & $\begin{array}{l}-.00009 \\
(-2.00)^{\text {thk }}\end{array}$ & $\begin{array}{l}.0013 \\
(2.00)^{\text {An }}\end{array}$ & .26 & $.7 .44 . \mathrm{Am} \mathrm{An}$ \\
\hline 7 & $\frac{.13}{(2.73) \text { *hn }}$ & - & - & - & -- & -- & - & $\begin{array}{c}-.001 \\
(-2.16)^{\text {Ak }}\end{array}$ & $\begin{array}{l}.15 \\
(3.17)^{\text {AnA }}\end{array}$ & $\begin{array}{l}-.0018 \\
(-1.86)^{\text {Ant }}\end{array}$ & $\begin{array}{l}-.00001 \\
(i .51)^{4}\end{array}$ & $(5.56)^{\text {AnA }}$ & $\frac{-.00007}{(-i .47)^{4}}$ & $\frac{.0019}{(2.57)^{\text {AnA }}}$ & .27 & $3.98 \cdot \mathrm{AABA}$ \\
\hline
\end{tabular}

NOTES: 1) SIGME is the annualized standard devtation of equity returns;

2) $\mathrm{AOB}, A C O N M, A P A R T, A S L C, A C L C, A S W A P$ and AOBS represent seven

3) LEV, DIV, AGAP, ALOSS, POR and ASIZE represent fInanclal lever-

age, diversiflication index, Interest rate risk, credit rlsk,

dividend payout and logarlithm of assets respectively;

1) Humbers in the parentheses are t-stat/stics;
5) significance level: $\quad=10 x_{i}$ an $=5 x_{i}$ ant $=18$. 


\section{TABLE 5}

Pooled Cross-Section and Tlme-Serles Results
(Dependent Varfable: BEIA)

\begin{tabular}{|c|c|c|c|c|c|c|c|c|c|c|c|c|c|c|c|c|}
\hline $\begin{array}{l}\text { Equactions } \\
\text { Ho, }\end{array}$ & Conasent & $\triangle 0 B$ & $\mathrm{ACOHM}$ & $\triangle P B A R T$ & $\Delta S L C$ & $\triangle$ ALLC & ASHAP & COAS & LEK & DIV & $\triangle G A P$ & n.oss & $\mathrm{POB}$ & ASIZE & $\bar{B}^{2}$ & $P(8,152)$ \\
\hline 1 & $\begin{array}{c}10.58 \\
(4.78)^{n A k}\end{array}$ & $\begin{array}{c}-.008 \\
(-.19)\end{array}$ & - & -- & - & $\cdots$ & - & - & $\begin{array}{c}10.64^{:} \\
(4.75)^{\text {thth }}\end{array}$ & $\frac{-.09 \text { AAA }}{(-2.55)^{\text {AMA }}}$ & $\begin{array}{r}-.00003 \\
(-.05)\end{array}$ & $(3.29)^{9.32}$ & $\frac{-.0048}{(-.70)}$ & $(-.024)$ & .14 & $3.58^{n+\pi \mathrm{m}}$ \\
\hline 2 & $\begin{array}{c}10.29 \\
(4.67)^{4 h A}\end{array}$ & -- & $\begin{array}{l}-.067 \\
(-.56)\end{array}$ & :- & - & - & $\cdots$ & - & $\begin{array}{c}10.37 \\
(4.61)^{\text {than }}\end{array}$ & $\begin{array}{l}-0.082 \\
(-2.47) \text { \#An }\end{array}$ & $\frac{-.000002}{(-.003)}$ & ${ }^{9.36}(3.50)^{n k k}$ & $\begin{array}{l}-.0046 \\
(-.68)\end{array}$ & $\begin{array}{l}.025 \\
(.86)\end{array}$ & .13 & 9.28 An \\
\hline 3. & $\begin{array}{c}10.54 \\
(4.76) \star \star \star A\end{array}$ & - & - & $\begin{array}{l}-.02 \\
(-.16)\end{array}$ & - & $\cdots$ & - & -- & $\begin{array}{c}10.53 \\
(4.75)\end{array}$ & $\frac{-.087}{(-2.55) \text { AAA }}$ & $\frac{-.00002}{(-.045)}$ & $\begin{array}{c}9.18 \\
(3.48)^{\text {AnA }}\end{array}$ & $\begin{array}{l}-.0047 \\
(-.68)\end{array}$ & $\begin{array}{r}-.021 \\
(-.78)\end{array}$ & .14 & 3.54 nkth \\
\hline 4 & $\begin{array}{c}9.14 \\
(4.12) \text { A*A }\end{array}$ & - & - & - & $\begin{array}{l}-1.10 \\
(-1.68)^{\mathrm{AA}}\end{array}$ & - & -- & - & $\begin{array}{c}9.60 \\
(4.26)^{\text {knt }}\end{array}$ & $\begin{array}{c}-.09 \\
(-2.60) \text { thk }\end{array}$ & $\begin{array}{r}-.00005 \\
(-.08)\end{array}$ & $\begin{array}{l}9.88 \\
(3.64)^{\# A \hbar}\end{array}$ & $\begin{array}{l}-.004 \\
(-.58)\end{array}$ & $(1.53)^{.051}$ & .12 & $2.95 \mathrm{AAn}$ \\
\hline 5 & $\begin{array}{c}10.57 \\
(4.80) \star A A\end{array}$ & - & - & - & - & $\begin{array}{l}.82 \\
(.44)\end{array}$ & - & - & $(4.74)^{10.52}$ & $\begin{array}{l}-.09 \\
(-2.33)^{\# A \hbar}\end{array}$ & -.00002 & $(3.46)^{9.06}$ & $\begin{array}{l}-.004 \\
(-.68)\end{array}$ & (.72) & .15 & $3.88: \hbar \star \hbar$ \\
\hline 6 & $(4.68)^{10.42}$ & - & - & - & -- & - & $\begin{array}{c}.06 \\
(1.08)\end{array}$ & - & $\begin{array}{c}10.12 \\
(4.44)\end{array}$ & $\begin{array}{c}-.08 \\
(-2.37)^{* \star A 4}\end{array}$ & $\begin{array}{r}-.00006 \\
(-.08)\end{array}$ & $(2.84)^{7.84 *}$ & $\begin{array}{r}-.004 \\
(.08)\end{array}$ & $\begin{array}{l}.005 \\
(.16)\end{array}$ & .15 & 3.94 inkA \\
\hline 7 & $\begin{array}{c}10.60 \\
(4.79) * \text { A A }\end{array}$ & - & - & - & - & - & - & $\begin{array}{l}-.002 \\
(-.07)\end{array}$ & $\begin{array}{c}10,51 \\
(4.65)^{\text {ath }}\end{array}$ & $\begin{array}{l}-.088 \\
(-2.50)^{\# A 4}\end{array}$ & $\begin{array}{r}-.00005 \\
(-.07)\end{array}$ & $\begin{array}{l}8.95 \\
(3.13)^{\text {nhth }}\end{array}$ & $\begin{array}{l}-.004 \\
(-.69)\end{array}$ & $\begin{array}{l}.015 \\
(.44)\end{array}$ & .15 & 3.54. AkA \\
\hline
\end{tabular}

HOTES: 1) BETA is the systematic r/sk

2) $A 0$, ACOMA, APART, ASLC, ACLC, ASWAP and AOBS represent seven

3) LEV, DIV, AGAP, ALOSS, POR and ASIZE represent fInanclal lever age, diversification index Interest rate rlsk, credit risk,
dividend payout Humbers in the parentheses are t-stutlstics:

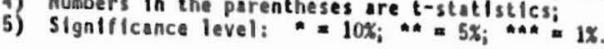

